\title{
The Transformation of Customer Satisfaction Become Customer Delight
}

\author{
Christian Wiradendi Wolor \\ Human Resource Management, The State University of Jakarta, Indonesia \\ E-mail: chrisden@windowslive.com
}

Hady Efendy

Education Practice and Academic Consultant, Indonesia

E-mail: efendy_hady@yahoo.co.id

Received: Oct. 9, 2017 Accepted: Oct. 18, $2017 \quad$ Published: Oct. 26, 2017

doi:10.5296/csbm.v4i2.11946 URL: http://dx.doi.org/10.5296/csbm.v4i2.11946

\begin{abstract}
Consumer satisfaction is considered a prerequisite for the emergence of positive behavior. It is not always the case. Several previous studies have suggested that it is not enough to simply provide satisfaction for customers because there is some low correlation between satisfaction and loyalty. This may explain why satisfied customers still leave the company. Executives from reputable companies engaged in services affirm that it is not enough to simply provide customer satisfaction, and is a priority to drive customer satisfaction into customer delight. The aim of this research is to analyze the influence of customer delight in improving customer commitment and customer loyalty. The field method and questionnaires were used to collect data. Statistical tools used in this research is Structural Equation Model (SEM). Data are analyzed by using statistical software LISREL 8.5. The result shows that brand trust, customer satisfaction, customer delight, customer commitment have positive effect on customer loyalty. Customer delight has the most influence on customer loyalty.
\end{abstract}

Keywords: Brand Trust, Customer Satisfaction, Customer Delight, Customer Commitment, Customer Loyalty 


\section{Introduction}

Free competition in this globalization era promises a new business opportunity and challenge for every company. Every company always strives to create satisfaction and even beyond that satisfaction that is happiness for its customers. Nowadays the competition between companies is also getting tighter as more and more new brands emerge. Of course, the company wants to get a special place in the hearts of consumers. Various ways to achieve this goal. Of course, the Company must be able to adapt to any changes that occur, such as social change, cultural change, lifestyle changes, and much more. The consequences of intense competition also require the company to provide the best service in satisfying its customers to win the competition and maintain its exclusion. Companies are not enough just to produce goods and services of quality in accordance with the desires and needs of consumers with an attractive price, which must be implemented company is placing customer satisfaction as the main goal that will be the key to the success and existence of the company. One strategy that can be used by companies is to build customer loyalty.

The existence of a trust within an affiliated brand creates a loyalty. Lau \& Lee (1999, p. 344) stated that trust in the brand is the willingness of consumers to trust the brand with all the risks because of the expectations promised by the brand in providing positive results for consumers.

Customer commitment to the brand is also important in shaping a consumer loyalty to a brand. Walsh et al. (2007, p. 54) says, brand commitment has been shown to play an important role in determining resistance to various actions such as attacks on certain brands.

Customer loyalty is absolutely required by a company to be able to survive and can compete with other companies. Consumer loyalty in general according to Siswar \& Fund (2011, p. 1) is loyalty to one of several products, whether it be goods or services. Further funding, loyalty is very important for companies that want to maintain the continuity and success of their business. Margaretha \& Moureen (2004, p. 25), consumer loyalty is the ticket to success in any business. Kandampully \& Suhartanto in Badawi (2007, p. 113) say, several studies have led to customer satisfaction as the starting point of customer loyalty growth.

Consumer satisfaction is considered a prerequisite for the emergence of positive behavior. In reality it is not always the case. Rowley \& Dawes (2000, p. 540) say, satisfied consumers are still doing the transfer of brands, otherwise disgruntled consumers remain a loyal customer. Afwan \& Putri (2009, p. 71) say, executives from reputable companies engaged in services assert that is not enough to just provide satisfaction for customers, and is a priority to move customer satisfaction into customer delight. Sri Sudarmiyati (2008, p. 123) also added that the delight of potentially to become a weapon in winning business competition.

\section{Literature Review}

\subsection{Customer Loyalty}

Maydeu et al. (2003, p. 289) says, consumer loyalty is a very important goal for strategic marketing planning and reflects the important basis for developing a competitive advantage. 
Kotler \& Keller (2009, p. 138) say, loyalty is "a strong commitment to buy back or reuse products or services selected in the future despite the influence of marketer circumstances and efforts in getting the potential to cause brand switching behavior.” Pong (2002, p. 4) suggests eight measures to measure consumer loyalty: Purchase Behavior, mouth-to-mouth recommendations, periods of use, price tolerance, buy-back intensity, preference, choice in reducing product choices, and first remembered.

\subsection{Brand Trust}

Keller (1993, p. 8) says, a brand is a sign of belief in all intangible activities, no human touch, and can be a symbol of quality and assurance in building trust. Brand trust is much more important in terms of risk reduction if the perceived risk of consumers to purchase decisions is high. Morgan \& Hunt (1994, p. 22) also added the importance of building trust has been proven in maintaining buyer and seller relationships.

\subsection{Customer Satisfaction}

Oliver in Kaveh (2012, p. 5016) says, customer satisfaction is defined as a judgment that a product or service feature, or the product or service itself, provides a pleasurable level of consumption related fulfillment including the level of under or over fulfillment. Valeria Zeithaml \& Bitner (2000, p. 75) says consumer satisfaction is the consumer evaluation of a product or service, whether the product or service has met the needs and expectations.

\subsection{Customer Delight}

Chandler in Oliver et al. (1997, p. 313) says customer delight is the reaction of customers when they receive a service or product that not only satisfies, but provides unexpected value or unanticipated satisfaction. Customer satisfaction, which we have all worked hard to provide, is largely a static process that focused on today and deals with known circumstances and known variables. Providing customer delight is dynamic, forward-looking process that takes place primarily in the unknown environment going beyond satisfaction to customer delight will provide a distinct advantage to the company that does it first and does it well consistently. Paterson (1997, p. 54) says customer delight involves going beyond satisfaction to delivering what can be best described as a pleasurable experience for the client.

The delightful customer is an important asset to the company. Keiningham et al. (2004, p. 5) proves, the relationship is not linear between merely satisfied with loyalty, and describes it in a curve called Delight Curve.

According to Keiningham et al. (2004, p. 5), most companies today only explore the middle area of the Delight Curve, an area called Zone of Mere Satisfaction. In the Zone of Mere Satisfaction companies simply "play safe" trying to keep their customers from being disappointed. In this area increased consumer satisfaction is not accompanied by a significant increase in loyalty. The first area, called Zone of Pain. In this area the company's services cause dissatisfaction with the consumers. In the third area, service improvements, however small, increase the level of customer satisfaction. This area is called Zone of Delight. 


\section{The Delight Response Curve}

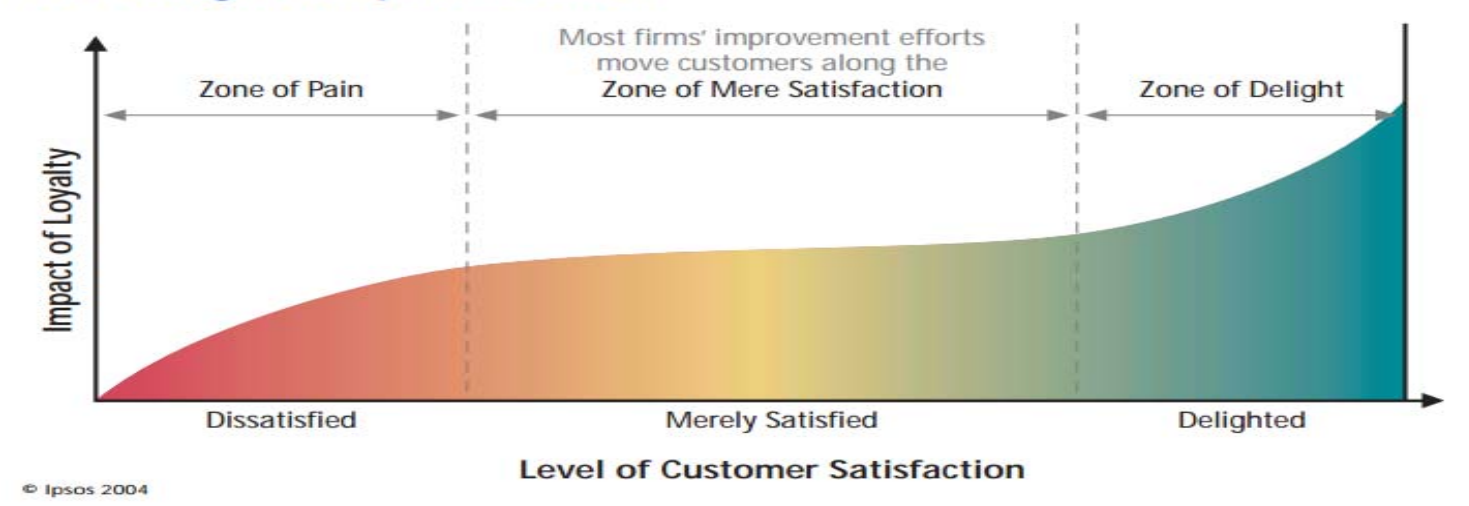

Figure 1. Delight Curve

Source: Keiningham et al. (2004, p. 5)

\subsection{Customer Commitment}

Beatty \& Kahle (1988, p. 4) says brand commitment as an emotional or psychological attachment to a brand within a product class. Similarly, brand commitment was defined as an average consumer's long-term behavioral and attitudinal disposition towards a relational brand. Moorman et al. (1992, p. 316) says Brand commitment can be viewed as "an enduring desire to maintain a valued relationship" with the brand.

\section{Hypothesis Development}

\subsection{Brand trust as a Driver of Customer Satisfaction, Customer Commitment, Customer Loyalty}

Belaid \& Temessek Behi (2010, p. 13) say, when consumers feel that the brand has fulfilled commercial promise and considering the welfare and interests of consumers, a thorough evaluation of brand performance will be positive. Thus, it can be said that the brand is trusted is a satisfactory brand. Crosby et al. (1990, p. 70) says, trust and satisfaction are positively correlated. Lawrence A. Crosby added explaining brand trust arises from past experiences and when interaction is then it is developed and described in the process of individual learning experience repeatedly. Therefore, brand trust is then fused in consumer knowledge and experience to the brand. If a consumer believes in a brand based on experience, then the customer will be satisfied with their purchase.

Morgan \& Hunt (1994, p. 24) explains, trust a significant impact on the commitment which also makes business exchange relationships become valuable, and Morgan states that trusts a significant impact in maintaining a relationship. Moorman et al. (1992, p. 316) says, trust leads to commitment in a reciprocal relationship. Moorman et al., Adding to the many possibilities that are at risk, trust is expected to increase the commitment in the relationship between consumers and companies. Kennedy et al. (2001, p. 77) says that there is a positive relationship between trust and commitment. Trust will be the forerunner of consumer commitment is 
defined as intent implicit or explicit to maintain durable relationships between consumers and companies.

Chaudhuri \& Holbrook (2001, p. 83) says, trust plays an important role in the domain of the brand associated with loyalty. Delgado-Ballester \& Munuera-Aleman (2001, p. 1245) said, trust leads to customer loyalty. Reichheld \& Schefter (2000, p. 107) say that to attain loyalty, one must first achieve trust first. Jahizatus Sa'adah (2011, p. 23) said that the higher consumer confidence resulted in higher consumer loyalty. Christopher W. Hart \& Johnson (1999, p. 11) says trust is a very powerful emotion, and will have a huge impact on loyalty.

\subsection{Customer Satisfaction as a Driver of Customer Commitment, Customer Loyalty}

Hess \& Story (2005, p. 315) say that satisfaction will affect the beliefs of the functional relationship of brands and personal relationships to commitment. Hennig-Thurau et al. (2002, p. 237) says that, very strong customer satisfaction related to the development of komitmnen. Wetzels et al. (1998, p. 410) said consumer satisfaction positive experience repeated and strong leads to a formation of affective commitment and calculative commitment, which is a component of the commitment itself.

Saputra (2008, p. 82) said, consumer satisfaction is reflected from the repurchase behavior and recommend to others positively. Satisfaction does not necessarily lead to loyalty, but loyalty usually begins with satisfaction first. From these explanations, clear relationship between customer satisfaction and customer loyalty, as also stated by Shankar et al., In Suparno Saputra (2008, p. 86) says that overall consumer satisfaction has a positive effect on customer loyalty. Zeithaml \& Bitner (2000, p. 80) say that consumer satisfaction causes a positive influence on loyalty.

\subsection{Customer Delight As A Driver of Customer Commitment, Customer Loyalty}

Edwards (2004, p. 1) on its website says, when we give pleasure (delight) to consumers who will buy products or services we sell, we create a strong emotional response where consumers will commit to the products or services we sell. Bernard \& Dozier (2011, p. 254) says, if someone is already delight will surely show that the person has committed. Veronica Oliver in Liljander \& Inger (2002, p. 595) says, the customer will be commit because they got something big and unexpected that instead of a habit. Verma (2003, p. 123) says, delight zone is an area where customers are happy or excited, which will lead to the commitment and loyalty.

Jones \& Seasser (1995, p. 91) exemplifies the events experienced by Xerox which, Xerox reports have found that customers were "Totally Satisfied" or delight, six times more often than customer repurchase are only satisfied only. Verma (2003, p. 123) says, delight zone is an area where customers are happy or excited, which will lead to the commitment and loyalty. Scholssberg in Oliver et al. (1997, p. 312) says that, Customer delight which is a higher level than the customer satisfaction is the key driver of loyalty and loyalty itself. Kline \& Edwin (2006, p. 2) says that the companies that deliver the experience of pleasure (delight) will have loyal customers. 


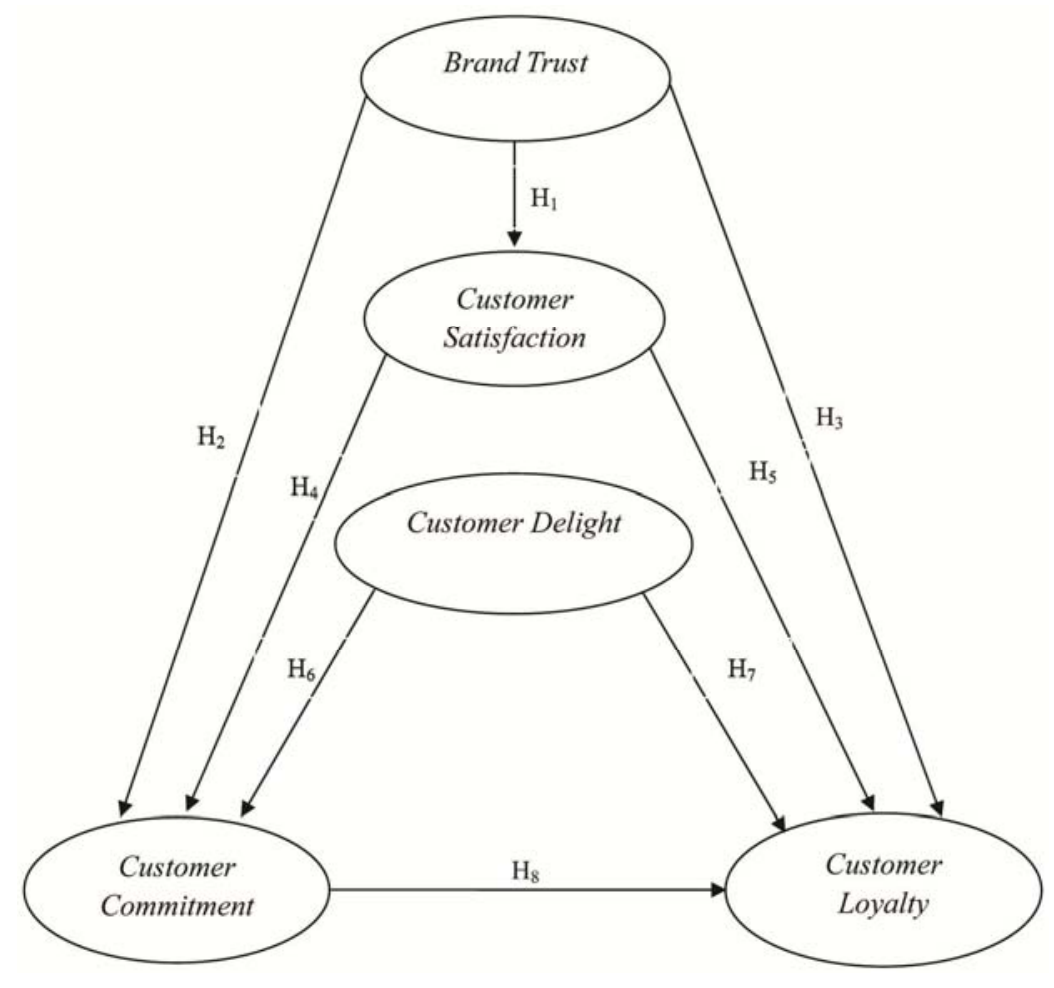

Figure 2. Conceptual model

\section{Methods}

Structural Equation Modeling or better known as SEM is a multivariate statistical analysis method. Doing if SEM data is different from doing if data regression or path analysis. SEM data is more complicated, because SEM is built by measurement models and structural models. To perform the data if SEM more easily, of course we need the help of statistical software. Currently already available various kinds of software for SEM data such as LISREL, AMOS and Smart PLS.

LISREL was developed by Jöreskog \& Sörbom. LISREL is the most widely used statistical software among researchers and practitioners. The advantage of the LISREL software is its ability to identify relationships between complex variables. How to operate it consists of various options, either with syntax or with a simple program, making it more widely used various circles. Syntax would be liked for users who are familiar with programming languages. While simples or simple LISREL is an alternative for those who are unfamiliar with programming languages. The various estimation methods are available in LISREL, so they are not fixed to one Maximum Likelihood estimation method. This depends on the data conditions, which estimation methods are used. One thing lacking of the LISREL software is the inability to process SEM data with a small sample size. When we have a sample of less than 200, while the model is complex, sometimes the estimation results do not match expectations.

Similar to SPSS, AMOS is a statistical software developed by IBM. AMOS software is devoted to help test the hypothesis of relationships between variables. Through AMOS 
software can be known the level of strength of the relationship between the variables either between the latent variable and the manifest variable. How significant is the relationship between variables, and how fit the hypothetical model is compared with real field data. The advantage of AMOS is that it does not require a syntax or a complicated programming language to operate this software. For beginners, or a layman with programming language is certainly an advantage in itself. Through AMOS, we simply describe the latent variables and manifest variables, then connect them through the available arrows. The advantages of AMOS as well as the lack of AMOS. Making very many images when the model is complex, would be a very tedious job. In fact, the work can be done more simply through programming languages. We live copy syntax and replace some variables, then running, then finished complex any model that would be made.

Smart PLS or Smart Partial Least Square is the same statistical software purpose with LISREL and AMOS that is to test the relationship between variables, both fellow variable latent as well as with indicator variable, or manifest. Smart PLS usage is greatly enhanced when we have limited number of samples while models are built complex. This cannot be done when we use both software above. They need sample adequacy. Another advantage of Smart PLS is its ability to process data both for formative or reflective SEM models. Formative SEM models have characteristics such as the latent or construct variables built by the indicator variable in which the arrow leads from the construct variable to the indicator variable. The reflective SEM model is a SEM model in which the construct variable is a reflection of the indicator variable, so the arrows lead from the indicator variable to the latent variable. Statistically, the consequence is there will be no error value on the indicator variable. Because this software is dedicated to doing data processing with small samples, it is not suitable for large sample research

Data collection techniques by means of written communication is by distributing questionnaires to 150 respondents who represent the Magnum Cafe, Jakarta. Retrieval technique used is purposive sampling that is where not everyone can become respondents in this study, but just who happens to be the current location of the data collection. Processing and analysis of data using multivariate techniques, Structural Equation Model (SEM), the software used is LISREL 8.5. The scale used is Likert. Analysis of the measurement model resulted in good fit and all items retained served as strong measures for their respective constructs $(\mathrm{CFI}>0.9$, IFI $>0.9$, RMSEA $<0.05)$.

\section{Results}

Based on the questionnaire data obtained the consumer profile of Magnum Cafe Jakarta which became the respondent in this research (See Table 1). 
Table 1. Profile of respondents

\begin{tabular}{|l|l|l|}
\hline & Number of Respondents & Percentage (\%) \\
\hline Gender & & \\
\hline Man & 83 & 55.33 \\
\hline Woman & 67 & 44.67 \\
\hline Age & & \\
\hline$<18$ Years & 23 & 15.33 \\
\hline $19-29$ Years & 77 & 51.33 \\
\hline $30-39$ Years & 36 & 24 \\
\hline $40-49$ Years & 10 & 6.67 \\
\hline$>50$ Years & 4 & 2.67 \\
\hline Work & & \\
\hline Employees & 39 & 26 \\
\hline Entrepreneur & 17 & 11.33 \\
\hline Student / Student & 83 & 55.33 \\
\hline Others & 11 & 7.33 \\
\hline Visit Intensity & & \\
\hline Not Every Month & 17 & 11.33 \\
\hline 1 time & 32 & 21.33 \\
\hline $2-3$ times & 55 & 36.67 \\
\hline $4-5$ times & 28 & 18.67 \\
\hline$>5$ Times & 18 & 12 \\
\hline
\end{tabular}

\subsection{Validity and Reliability}

The validity of an indicator can be evaluated by the level of significance of the influence between a latent variable with its indicator. Item question declared invalid if the t-value $>1.96$ (Yamin \& Kurniawan, 2009, p. 36) factor loading $\geq 0.4$ (Waluyo, 2011, p. 81). All the questions that are 40 items declared valid question because the t-value $>1.96$ and factor loading $\geq 0.4$.

Table 2. Reliability

\begin{tabular}{|l|l|}
\hline Latent Variables & Construct Reliability \\
\hline Brand Trust & 0.91 \\
\hline Customer Satisfaction & 0.74 \\
\hline Customer Delight & 0.84 \\
\hline Customer Commitment & 0.96 \\
\hline Customer Loyalty & 0.96 \\
\hline
\end{tabular}

Source: Processed Data.

Based on Table 2. The value of Construct Reliability of each latent variable is above a critical limit is 0.7 . Construct Reliability with value which is above the limit, then the indicator 
variable has the consistency of a good measurement of the latent variable represents.

\subsection{Fit Model Rating}

From Table 5, can be seen that the value of Chi-square and value $p=(0.00<0.05)$, this means no good model fit as desired is Chi-square value small $p>0.05$. RMSEA model is of 0.062 . This indicates that the goodness of fit model is quite good, but the P-Value for the Test of Close Fit $($ RMSEA $<0.05)=0.0034$ which indicates the model is not good. Although translation of the above stated that the model does not have a value fit enough, it is used another indicator to assess the suitability of the model: ECVI in the above table that is equal to 8.88 less than ECVI Saturated i.e. 11:01 and ECVI Independence that is equal to 29.54. This shows that the model has a good fit. AIC in the above table that is equal to 1323.34 is smaller than the AIC and AIC 1640.00 saturated namely Independence amounting to 4401.34 . This shows that the model has a good fit. CAIC in the above table that is equal to 1680.29 is smaller than Saturated CAIC is 4928.72 and CAIC Independence amounting to 4561.77. This shows that the model has a good fit. In the table shows the value of PGFI of 0.64 is greater than 0.6 . This shows that the model has a good fit. In the table shows the value of PNFI that is equal to 0.65 is greater than 0.6 . This shows that the model has a good fit. The value of $0.8 \leq \mathrm{CFI} \leq 0.9$ is the marginal fit (good enough). The CFI value table is 0.83 . This shows that the model has a good fit. The value of 0.8 $\leq \mathrm{IFI} \leq 0.9$ is marginal fit (good enough). In the table IFI value that is equal to 0.83 . This shows that the model has a good fit.

\subsection{Hypothesis Testing}

The results of hypothesis testing in accordance with the model presented in appendix 1, can be seen in the appendix and summaries are presented in Table 3. Testing the research hypothesis is done by testing the relationship between latent variables. A relationship was significant if it has a t-value $>1.65$. Of the eight hypotheses proposed, the eight hypotheses have enough evidence to positively and significantly influence.

Effect of brand trust on customer satisfaction is at 0.23 (Table 4). Effect of brand trust on customer commitment is $0: 18$. Effect of brand trust on customer loyalty is at 0.23 . The indirect effect on customer brand trust through customer satisfaction commitment is 0.05 . Effect of brand trust on customer loyalty through customer satisfaction is at 0:08. Effect of brand trust on customer loyalty through customer commitment is of 0.03 . Effect of brand trust on customer loyalty through customer satisfaction and customer commitment is 0.01 . The influence of customer satisfaction on customer commitment is equal to 0.20 . The influence of customer satisfaction on customer loyalty is at 0:36. The indirect effect on customer loyalty customer satisfaction through customer commitment is at 0:04. Influence on customer commitment, customer delight is at 0:21. Influence customer delight on customer loyalty is at 0:38. The indirect effect of customer delight on customer loyalty through customer commitment is at 0:04. Effect of customer commitment to customer loyalty is of 0:18. 
Table 3. Causal relationships between variables

\begin{tabular}{|l|l|l|}
\hline Groove (Path) & Coefficient of Standardization & T value \\
\hline Brand Trust $\rightarrow$ Customer Satisfaction & 0.23 & $2: 36^{*}$ \\
\hline Brand Trust $\rightarrow$ Customer Commitment & 0.18 & $2: 08^{*}$ \\
\hline Brand Trust $\rightarrow$ Customer Loyalty & 0.23 & $2.74^{*}$ \\
\hline $\begin{array}{l}\text { Customer Satisfaction } \rightarrow \text { Customer } \\
\text { Commitment }\end{array}$ & 0.20 & $2: 06^{*}$ \\
\hline Customer Satisfaction $\rightarrow$ Customer Loyalty & 0.36 & $3.63^{*}$ \\
\hline Customer Delight $\rightarrow$ Customer Commitment & 0.21 & $2: 32^{*}$ \\
\hline Customer Delight $\rightarrow$ Customer Loyalty & 0.38 & $4: 20^{*}$ \\
\hline Customer Commitment $\rightarrow$ Customer Loyalty & 0.18 & $2: 14^{*}$ \\
\hline
\end{tabular}

Note. * significant at $\alpha=0.05$.

Table 4. Direct, indirect, and total influence

\begin{tabular}{|l|l|l|l|l|l|}
\hline From & Through & To & $\begin{array}{l}\text { Direct } \\
\text { Effect }\end{array}$ & $\begin{array}{l}\text { Indirect } \\
\text { Influence }\end{array}$ & Total Influence \\
\hline \multirow{2}{*}{ Brand Trust } & Customer Satisfaction & $\begin{array}{l}\text { Customer } \\
\text { Loyalty }\end{array}$ & 0.23 & 0.08 & 0.35 \\
\cline { 2 - 5 } & Customer Commitment & & 0.03 \\
\cline { 2 - 5 } & $\begin{array}{l}\text { Customer Satisfaction and } \\
\text { Customer Commitment }\end{array}$ & & 0.01 & \\
\hline $\begin{array}{l}\text { Customer } \\
\text { Satisfaction }\end{array}$ & Customer Commitment & $\begin{array}{l}\text { Customer } \\
\text { Loyalty }\end{array}$ & 0.36 & 0.04 & 0.40 \\
\hline $\begin{array}{l}\text { Customer } \\
\text { Delight }\end{array}$ & Customer Commitment & $\begin{array}{l}\text { Customer } \\
\text { Loyalty }\end{array}$ & 0.38 & 0.04 & 0.42 \\
\hline $\begin{array}{l}\text { Brand Trust } \\
\text { Customer } \\
\text { Satisfaction }\end{array}$ & Customer Satisfaction & $\begin{array}{l}\text { Customer } \\
\text { Commitment }\end{array}$ & 0.18 & 0.05 & 0.23 \\
\hline $\begin{array}{l}\text { Customer } \\
\text { Delight }\end{array}$ & $\begin{array}{l}\text { Customer } \\
\text { Commitment }\end{array}$ & 0.20 & - & 0.20 \\
\hline Brand Trust & $\begin{array}{l}\text { Customer } \\
\text { Commitment }\end{array}$ & 0.21 & - & 0.21 \\
\hline $\begin{array}{l}\text { Customer } \\
\text { Commitment }\end{array}$ & & $\begin{array}{l}\text { Customer } \\
\text { Satisfaction }\end{array}$ & 0.23 & - & 0.23 \\
\hline
\end{tabular}




\title{
II Macrothink
}

Table 5. Overall model fit

\author{
Degrees of Freedom $=731$ \\ Minimum Fit Function Chi-Square $=1323.66(\mathrm{P}=0.0)$ \\ Normal The ory Weighted Least Squares Chi-Square $=1145.34(\mathrm{P}=0.0)$ \\ Estimated Non-centrality Parameter (NCP) $=414.34$ \\ 90 Percent Confidence Interval for $\mathrm{NCP}=(326.41 ; 510.20)$ \\ Minimum Fit Function Value $=8.88$ \\ Population Discrepancy Function Value $(\mathrm{F} 0)=2.78$ \\ 90 Percent Confidence Interval for $\mathrm{F} 0=(2.19 ; 3.42)$ \\ Root Mean Square Error of Approximation (RMSEA) $=0.062$ \\ 90 Percent Confidence Interval for RMSEA $=(0.055 ; 0.068)$ \\ P-Value for Test of Close Fit (RMSEA $<0.05)=0.0034$ \\ Expected Cross-Validation Index (ECVI) $=8.88$ \\ 90 Percent Confidence Interval for ECVI $=(8.29 ; 9.52)$ \\ ECVI for Saturated Mode1 $=11.01$ \\ ECVI for Independence Model $=29.54$ \\ Chi-Square for Independence Model with 780 Degrees of Freedom $=4321.34$ \\ Independence $\mathrm{AIC}=4401.34$ \\ Model $\mathrm{AIC}=1323.34$ \\ Saturated $\mathrm{AIC}=1640.00$ \\ Independence $\mathrm{CAIC}=4561.77$ \\ Model CAIC $=1680.29$ \\ Saturated CAIC $=4928.72$ \\ Normed Fit Index (NFI) $=0.69$ \\ Non-Normed Fit Index (NNFI) $=0.82$ \\ Parsimony Normed Fit Index (PNFI) $=0.65$ \\ Comparative Fit Index $(\mathrm{CFI})=0.83$ \\ Incremental Fit Index (IFI) $=0.83$ \\ Relative Fit Index (RFI) $=0.67$ \\ Critical $\mathrm{N}(\mathrm{CN})=93.63$ \\ Root Mean Square Re sidual (RMR) $=0.096$ \\ Standardized RMR $=0.088$ \\ Goodness of Fit Index (GFI) $=0.72$ \\ Adjusted Goodness of Fit Index (AGFI) $=0.69$ \\ Parsimony Goodness of Fit Index (PGFI) $=0.64$
}

Table 6. Conformity of structural model

\begin{tabular}{|l|l|}
\hline 1 & $\mathrm{CS}=0: 23 * \mathrm{BT}$, Errorvar. $=0.95, \mathrm{R}^{2}=0054$ \\
& $(0.099)(0.21)$ \\
& 2.364 .55 \\
\hline 2 & $\mathrm{CC}=0: 20 * \mathrm{CS}+\mathrm{BT}+0: 210: 18 * * \mathrm{CD}$, Errorvar. $=0.84, \mathrm{R}^{2}=0: 16$ \\
& $(0.095)(0.089)(0.089)(0.14)$ \\
& 2.062 .082 .325 .87 \\
\hline 3 & $\mathrm{CL}=\mathrm{CS}+0: 180: 36 * * \mathrm{CC}+\mathrm{BT}+0: 380: 23 * * \mathrm{CD}$, Errorvar. $=0: 45, \mathrm{R}^{2}=0: 55$ \\
& $(0.098)(0.082)(0.085)(0.091)(0.12)$ In the first place, \\
& 3.632 .142 .744 .203 .69 \\
\hline
\end{tabular}


Compatibility of structural model seen from the value of $\mathrm{R} 2$. The result of structural model of analysis of yields of three structural equations which show the influence between variables. From the first known structural equation R $2=0054$, which means that customer satisfaction can be explained by the brand trust of $5.4 \%$. The second structural equation known $\mathrm{R} 2=$ $0: 16$, which means customer satisfaction, brand trust and customer delight by $16 \%$. The third structural equation known R $2=0: 55$, which means that customer loyalty can be explained by customer satisfaction, brand trust, customer delight, and customer commitment by $55 \%$.

\section{Discussion}

Effect of brand trust to the customer satisfaction is positive ( $0: 23)$ and significant $(2: 36>1.65)$. Thus, it can be said brand trust has a positive effect on customer satisfaction by $23 \%$. The results are consistent with the theory put forward by Belaid \& Behi $(2010$, p. 13) says, when consumers feel that the brand has fulfilled the commercial promise and consider the welfare and interests of consumers, a thorough evaluation of the performance of the brand will be positive. Thus it can be said that the brand is trusted brand is satisfactory. Crosby et al. (1990, p. 70) says, trust and satisfaction are positively correlated. Lawrence A. Crosby added explaining brand trust arises from past experiences and when interaction is then it is developed and described in the process of individual learning experience repeatedly. Therefore, brand trust is then fused in consumer knowledge and experience to the brand. If consumers trust the brand based on past experience, the consumer will be satisfied with their purchases.

Effect of brand trust to the customer commitment is positive $(0.18)$ and significant $(2: 08>$ 1.65). Thus, it can be said brand trust has positive influence on customer commitment by $18 \%$. The results are consistent with the theory put forward by Morgan \& Hunt (1994, p. 24) explains, trust a significant impact on the commitment which also makes the relationship business exchange valuable, and also Morgan states that trusts a significant impact in maintaining a relationship. Moorman et al. (1992, p. 316) says, trust leads to commitment in a reciprocal relationship. Moorman et al., Adding to the many possibilities that are at risk, trust is expected to increase the commitment in the relationship between consumers and companies. Kennedy et al. (2001, p. 77) says that there is a positive relationship between trust and commitment. Trust will be the forerunner of consumer commitment is defined as intent implicit or explicit to maintain durable relationships between consumers and companies.

Effect of brand trust to customer loyalty is positive (0:23) and significant (2.74>1.65). Thus, it can be said brand trust has a positive effect on customer loyalty by $23 \%$. The results are consistent with the theory put forward by Chaudhuri \& Holbrook (2001, p. 83) says, trust plays an important role in the domain of the brand associated with loyalty. Delgado-Ballester \& Munuera-Aleman (2001, p. 1245) said, trust leads to customer loyalty, Frederick F. Reichheld $\&$ Schefter (2000: 107) says that in order to achieve loyalty, one must first attain the trust first. Sa'adah (2011, p. 23) says that higher consumer confidence resulted in the higher customer loyalty. Hart \& Johnson (1999, p. 11) says trust is a very powerful emotion, and will have a huge impact on loyalty.

Effect of customer satisfaction to customer commitment is positive $(0.20)$ and significant $(2: 06>1.65)$. Thus, it can be said customer satisfaction has positive influence on customer 
commitment by $20 \%$. The results are consistent with the theory put forward by Jeff Hess \& John Story (2005: 315) says that satisfaction will influence brand trust functional relationships and personal relationships towards commitments. Hennig-Thurau et al. (2002, p. 237) says that, customer satisfaction is very strongly related to the development of commitment. Wetzels et al., (1998: 410) said consumer satisfaction positive experience repeated and strong leads to a formation of affective commitment and calculative commitment, which is a component of the commitment itself.

Effect of customer satisfaction to customer loyalty is positive (0.36) and significant (3.63> 1.65). Thus, it can be said customer satisfaction positively affects customer loyalty by $36 \%$. The results are consistent with the theory put forward by Saputra (2008, p. 82) says, consumer satisfaction is reflected in the behavior of repeat purchase and recommend to others positively. Satisfaction does not necessarily lead to loyalty, but loyalty usually begins with satisfaction first. From these explanations clear relationship between customer satisfaction and customer loyalty, as also stated by Shankar et al., in Suparno Saputra (2008,p. 86) says that overall consumer satisfaction has a positive effect on customer loyalty. Valeria A. Zeithaml \& Bitner (2000, p. 80) say that customer satisfaction lead to a positive influence for loyalty.

Effect of customer delight to customer commitment is positive (0.21) and significant (2:32> 1.65). Thus, it can be said customer delight positive influence on customer commitment by $21 \%$. The results are consistent with the theory put forward by Edwards $(2004$, p. 1) on its website says, when we give pleasure (delight) to consumers who will buy products or services we sell, we create an emotional response that is strong where consumers will commit the products or services we sell. Bernard \& Dozier (2011, p. 254) says, if someone had delight would certainly indicate that the person has committed. Veronica Oliver in Liljander \& Inger (2002, p. 595) says, the customer will be commit because they got something big and unexpected that instead of a habit. It shows of similarity with sense of delight expressed by Chandler in Oliver et al. (1997, p. 313), namely, customer delight focus on what is currently unknown or unanticipated by the customer. Verma (2003, p. 123) says, zone delight is an area where customers are happy or excited, which will lead to the commitment and loyalty.

Effect of customer delight to customer loyalty is positive (0.38) and significant (4:20>1.65). Thus, it can be said customer delight positive effect on customer loyalty by $38 \%$. The results are consistent with the theory put forward by Jones \& Seasser (1995, p. 91) exemplifies the events experienced by Xerox which, Xerox reports have found that customers were "Totally Satisfied" or delight, six times more often than its repurchase customers are just satisfied only. Verma (2003, p. 123) says, zonedelight is an area where customers are happy or excited, which will lead to the commitment and loyalty. Scholssberg in Oliver et al. (1997, p. 312) says that, Customer delight which is a higher level than the customer satisfaction is the key driver of loyalty and loyalty itself. Kline \& Edwin (2006, p. 2) says that the companies that deliver the experience of pleasure (delight) will have loyal customers.

Effect of customer commitment to customer loyalty is positive (0.18) and significant $(2: 14>$ 1.65). Thus, it can be said customer commitment positively affects customer loyalty by $18 \%$. The results are consistent with the theory put forward by Darrel Edwards (Strategic Vision: 1) 
on its website says, a commitment will lead to loyalty. Fullerton (2003, p. 333) says, customer commitment is very important that as a driver of customer loyalty. Amine (1998, pp. 309-310) says, a higher commitment leads to a more positive behavioral loyalty. Soni et al. (Institute for the Study of Business Markets, p. 21) says that commitment leads to loyalty. Belaid \& Temessek (2010, p. 9) says, loyalty and commitment should be considered as phenomena related, but different. Loyalty is a construct of behavior and attitudes, especially attitudes while commitments. Belaid \& Temessek (2010, p. 9), said the brand's commitment relationship investigation has found that commitment plays a central role in predicting loyalty.

\section{Conclusions}

After testing the hypothesis of the hypotheses proposed in this study, the conclusions obtained are described as follows Brand trust, customer satisfaction, customer delight, customer commitment have positive and significant impact on customer Loyalty. So, it is advisable that the trust of the brand will be maintained while maintaining the quality of the product so it is expected to maintain customer satisfaction, customer commitment and customer loyalty. One of the big variables in improving customer loyalty in this research is customer delight. Customer delight is not just one way to win business competition in the future, but it is also an innovation in delivering a deeper and more enjoyable customer service not just to satisfy consumers.

\section{References}

Afsar, B. et al. (2010). Determinants of Customer Loyalty in the Banking Sector: The Case of Pakistan. Journal of Business Management, 4(6), 1040-1047.

Agustin, C., \& Jagdip, S. (2005). Curvilinear Determinants Effects of Consumer Loyalty in Relational Exchanges. Journal of Marketing Research, XLII, 96-108. https://doi.org/10.1509/jmkr.42.1.96.56961

Ahluwalia, R., Burnkrant, R. E., \& Raounnava, H. (2000). Consumer Response to Negative Publicity: Th Moderating Role of Commitment. Journal of Marketing Research, XXXVII, 203-214. https://doi.org/10.1509/jmkr.37.2.203.18734

Al Hawari, M. A. (2011). The Role of Bank Automated Services in Gaining Customers' Trust: A Practical Study in UAE. Journal of Management, 33, 45-52.

Amalia, S., \& Sri, R. (2008). Trimatra to Win Competition: Value, Quality of Service, and Delight. BENEFIT Journal of Management and Business, 12(2), 181-187.

Amine, A. (1998). Consumers' true brand loyalty: the central role of commitment. Journal of Strategic Marketing, 6, 305-319. https://doi.org/10.1080/096525498346577

AP, Afwan, H., \& Anindhita, A. (2009). The Effect of Customer Delight to Customer Loyalty. Journal of Business Economics Year, 14(1).

Badawi. (2007). The Effect of Trust In A Brand and Satisfaction Loyalty Brand. Bulletin of Economics, 5(2). 
Ballester, E. D., \& Munuera-Aleman, J. L. (2001). Brand trust in the context of consumer loyalty. European Journal of Marketing, 1238. https://doi.org/10.1108/EUM0000000006475

Bansal, H.S., Gregory Irving, P., \& Taylor, S. F. (2004). A Three-Component Model of Customer Commitment to Service Providers. Journal of the Academy of Marketing Science, 32(3), 234-250. https://doi.org/10.1177/0092070304263332

Barnes, D. C., Beauchamp, M., \& Bednarz, C. W. (2010). To Delight, or Not To Delight? This Is the Question Service Firms Must Address. Journal of Marketing Theory and Practice, 18(3), 275-283. https://doi.org/10.2753/MTP1069-6679180305

Bearden, W., \& Teel, J. E. (1983). Selected Determinants of Consumer Satisfaction and Complaint Reports. Journal of Marketing Research, $X X, 21-28$. https://doi.org/10.2307/3151408

Beatty, S. E., \& Lynn, R. K. (1988). Alternative hierarchies of the Attitude-Behavior Relationship: The Impact of Brand Commitment and Habit. Journal of the Academy of Marketing Science, 16(2), 1-10. https://doi.org/10.1007/BF02723310

Belaid, S. (2010). The Role of Attachment in Building Consumer-Brand Relationships: An Empirical Invetigation in Utilitarian Consumption Context. Woking Paper.

Berman, B. (2005). How to Delight Your Customers. California Management Review, 48(1). https://doi.org/10.2307/41166331

Bernard, K., \& Dozier, M. (2011). This Is My Baby: Foster Parents' Feelings of Commitment and Displays of Delight. Infant Mental Health Journal, 32(2), 251-262. https://doi.org/10.1002/imhj.20293

Bettencourt, L. A. (1997). Customer voluntary performance: Customers as partners in service delivery. Journal of Retailing, 383. https://doi.org/10.1016/S0022-4359(97)90024-5

Cater, B. (2007). Trust and Commitment in Professional Services Marketing Relationships in Business-to-Business Markets. Managing Global Transitions, 5(4).

Chaudhuri, A., \& Holbrook, M. B. (2001). The chain of effects from brand trust and brand Affect to brand performance: The role of brand loyalty. Journal of Marketing, 65, 81. https://doi.org/10.1509/jmkg.65.2.81.18255

Chitty, B., Ward, S., \& Chua, C. (2007). An Application seeking of the ECSI models as a predictor of satisfaction and loyalty for backpacker hostels. Marketing Intelligence \& Planning, 25(6). https://doi.org/10.1108/02634500710819941

Cooper, D. R., \& Schindler, P. S. (2008). Business Research Methods (10th edition). New York: McGraw-Hill.

Crosby, L. A., Evans, K. R., \& Cowles, D. (1990). Relationship Quality in Services Selling. Journal of Marketing, 68. https://doi.org/10.2307/1251817

Delgado-Ballester, E., Munuera-Alemán, J. L., \& Yague-Guillen, M. J. (2003). Development 
and Validation of a Scale Brand Trust. International Journal of Market Research.

Dick, A. S., \& Kunal, B. (1994). Customer Loyalty: Toward an Integrated Conceptual Framework. Journal of the Academy of Marketing Science, 22(2). https://doi.org/10.1177/0092070394222001

Edwards, D. (2004). [Online] Available: http://www.craigboren.com/strategicvision/mdv_main.htm

Erevelles, S., \& Leavitt, C. (1992). A Comparison of Current Model of Consumer Satisfaction / Dissatisfaction. Journal of Consumer Satisfaction, Dissatisfaction and Complaining Behavior, 5.

Finn, A. (2005). Reassessing the Foundations of Customer Delight. Journal of Service Research, 103. https://doi.org/10.1177/1094670505279340

Forouzandeh, S., \& Parviz, A. (2010). Maintaining Customer Loyalty in a De-Regulating Service Industry. Euro Journals.

Fullerton, G. (2003). When Does Commitment Lead to Loyalty?. Journal of Service Research, 333. https://doi.org/10.1177/1094670503005004005

Gabarino, E., \& Johnson, M. S. (1999). The different roles of satisfaction, trust, and commitment in customer relationship. Journal of Marketing, 70. https://doi.org/10.2307/1251946

Ganesan, S. (1994). Determinants of long-term orientation in buyer-seller relationships. Journal of Marketing, 1. https://doi.org/10.2307/1252265

Ganesh, J., Arnold, M. J., \& Reynolds, K. E. (2000). Understanding the customer base of $\begin{array}{llll}\text { Service Providers. Journal of } & \text { Marketing, 65-87. }\end{array}$ https://doi.org/10.1509/jmkg.64.3.65.18028

Geyskens, I. et al. (1996). The effects of trust and indepandence on comitment relationship. International Journal of Research in Marketing, 13, 303-317. https://doi.org/10.1016/S0167-8116(96)00006-7

Ghozali, I. (2008). Structural Equation Modeling (2nd edition). Publisher Agency: Semarang Diponegoro University.

Gruen, T. W., Summers, J., \& Acito, F. (2000). Relationship marketing activities, commitment, and membership in professional association's behaviors. Journal of Marketing, 34. https://doi.org/10.1509/jmkg.64.3.34.18030

Gundlach, G. T., Achrol, R. S., \& Mentzer, J. T. (1995). The structure of commitment in exchange. Journal of Marketing, 78. https://doi.org/10.2307/1252016

Gustafsson, A., Johnson, M. D., \& Roos, I. (2005). The Effects of Customer Satisfaction, Relationship Commitment Dimensions, and Triggers on Customer Retention. Journal of Marketing, 69, 210-218. https://doi.org/10.1509/jmkg.2005.69.4.210 
Hair, J. F. et al. (2010). Multivariate Data Analysis: A Global Perspective (7th edition.) New Jersey: Pearson

Hart, C. W., \& Johnson, M. D. (1999). Growing the Trust Relationship. Marketing Management.

Hasan, S. A., Saquib, R., \& Muhammad, I. S. (2011). Measuring Customer Delight: A Model for Banking Industry. European Journal of Social Sciences, 22(4).

Hellier, P. K. et al. (2003). Customer Repurchase Intention A General Structural Equation $\begin{array}{lllll}\text { Model. European Journal of } & \text { Marketing, }\end{array}$ https://doi.org/10.1108/03090560310495456

Hess, J., \& Story, J. (2005). Trust-Based Commitment: Multidimensional Consumer-Brand Relationships. The Journal of Consumer Marketing, 313. https://doi.org/10.1108/07363760510623902

Jones, T. O. \& Seasser, W. E. (1995). Why Satisfied Customers Defect. Harvard Bussiness Review.

Kaveh, M. (2012). Role of Trust in Explaining Repurchase Intention. African Journal of Business Management, 6(14), 5014-5025.

Keiningham, T. L., Pruden, D. R., \& Vavra, T. G. (2004). The Role of Customer Delight in Achieving Loyalty. Ipsos Loyalty.

Kennedy, M. S., Ferrell, L. K., \& Thorne, D. L. (2001). Consumers' trust of salesperson and manufacturer: an empirical study. Journal of Business Research, 51, 73-86. https://doi.org/10.1016/S0148-2963(99)00039-9

Kline, S. F., \& Torres, E. (2006). Hotel Customer Satisfaction to Delight: A Typography of Customer Delight in a Hotel Setting.

Kotler, P., \& Keller, K. L. (2009). Manajemen Pemasaran. Edisi Ketiga Belas, Jilid I, Terjemahan oleh Bob Sabran, Jakarta, Penerbit Erlangga.

Kumar, A., Olshavsky, R. W., \& King, M. F. (2001). Exploring Alternative Antecedents of Customer. Journal of Consumer Satisfaction, Dissatisfaction and Complaining Behavior, 14.

Kwong, K. K., \& Yau, O. H. M. (2002). The Conceptualization of Customer Delight: A Research Framework. Asia Pacific Management Review, 7(2), 255-266.

Latan, H. (2012). Structural Equation Modeling. Bandung: Penerbit Alfabeta

Lau, G. T., \& Lee, S. H. (1999). Consumers' Trust in a Brand and the Link to Brand Loyalty. Journal of Market-Focused Management, 341. https://doi.org/10.1023/A:1009886520142

Lewis, D. J., \& Weigert, A. (1985). Trust as a Social Reality. Chapel Hill: The University of North Carolina Press.

Liljander, V., \& Roos, I. (2002). Customer-Relationship Levels-From Spurious to True 
Relationships. The Journal of Services Marketing, 593. https://doi.org/10.1108/08876040210447333

Lu, T. P. J., \& Tang, E. P. Y. (2001). An Integrated Model of Service Loyalty. Academy of Business \& Administrative Sciences 2001 International Conferences.

Luarn, P., \& Lin, H. H. (2003). A Customer Loyalty Model for E-Service Context. Journal of Electronic Commerce Research, 4(4).

Margaretha, V. M. (2004). Skripsi: Analisis Pengaruh Kualitas Kinerja Pelayanan Terhadap Kepuasan Pelanggan, Reputasi Perusahaan, dan Loyalitas Pelanggan Pada Divisi Asuransi Kumpulan AJB Bumiputra 1912. Universitas Diponegoro.

Maydeu, A. O. (2003). Market orientation and business economic performance a mediated model. International Journal of Service Industry Management, 14(3).

McKnight, D. H., Choudhury, V., \& Kacmar, C. (2002). The impact of initial consumer trust on intentions to transact with a web site: a trust building model. Journal of Strategic Information Systems, 11, 297-323. https://doi.org/10.1016/S0963-8687(02)00020-3

Moorman, C., Zaltman, G., \& Deshpande, R. (1992). Relationships between Providers and Users of Market Research: The Dynamics of Trust within and Between Organizations. Journal of Marketing Research, XXIX, 314-328. https://doi.org/10.2307/3172742

Morgan, R. M., \& Hunt, S. D. (1994). The Commitment- Trust Theory of Relationship Marketing. Journal of Marketing, 58, 20-38. https://doi.org/10.2307/1252308

Musanto, T. (2004). Faktor-Faktor Kepuasan Pelanggan dan Loyalitas Pelanggan: Studi Kasus pada CV. Sarana Media Advertising Surabaya. Jurnal Manajemen \& Kewirausahaan, $6(2)$.

Ndubisi, N. O. (2007). Relationship marketing and customer loyalty. Marketing Intelligence \& Planning, 25(1). https://doi.org/10.1108/02634500710722425

N'goala, G. (2006). How to Make Customers Resist Switching to Another Service Provider When a Critical Incident Occurs? The Complementary Roles of Trust and Relationship Commitment. 9th International Research Seminar in Service Management.

Oliver, R. L. (1999). Whence Consumer Loyalty? Journal of Marketing, 63, 33-44. https://doi.org/10.2307/1252099

Oliver, R. L., Rust, R. T., \& Sajeev, V. (1997). Customer Delight: Foundations, Findings, and Managerial Insight. Journal of Retailing, 73(3), 311-336. https://doi.org/10.1016/S0022-4359(97)90021-X

Oliver, R. W. (1999). The Red Queen rules. The Journal of Business Strategy. https://doi.org/10.1108/eb039999

Papadopoulou, P. et al. (2001). Trust and relationship building in electronic commerce. Internet Research: Electronic Networking Applications and Policy, 11(4), 322-332. 
https://doi.org/10.1108/10662240110402777

Paterson, K. (1997). Delighted clients are loyal clients. Rough Notes, 140, 54.

Plutchick, R. (2001). The Nature of Emotions. American Scientist, 89. https://doi.org/10.1511/2001.4.344

Prawitowati, T. (2008). The Effect of Overall Satisfaction of Trust In Shaping Purchase Brand Loyalty and Attitudinal Loyalty In the Consumer Products Shampoo in Surabaya. Ventura, 11(1).

Pritchard, M. P., Havitz, M. E., \& Howard, D. R. (1999). Analyzing the Commitment-Loyalty Link in Service Contexts. Journal of the Academy of Marketing Science, 27(3), 333-348.

Reichheld, F. F. (1993). Loyalty-Based Management. Harvard Business Review.

Reichheld, F. F., \& Scefter, P. (2000). E-Loyalty: You're Weapon Secret on the Web. Harvard Business Review.

Rowley, J., \& Dawes, J. (2000). Disloyalty: a closer look at non-loyal. The Journal of Consumer Marketing. https://doi.org/10.1108/07363760010349948

Russell, J. A. (1980). A Model of Affect Cirumplex. Journal of Personality and Social Psychology, 39(6), 1161-1178. https://doi.org/10.1037/h0077714

Ruyter, K. D., Weitzels, M., \& Birgelen, M. V. (1999). How Do Customers React to Critical Service Encounters?: A Cross-Sectional Perspective. Total Quality Management, 10(8), 1131-1145. https://doi.org/10.1080/0954412997118

Sa'adaah, J., \& Fatchur, R. (2011). The Effect of Service Quality of Satisfaction, Trust, and Loyalty in Forming Word Of Mouth (Studies in Resto in Tuban). Postgraduate Economics and Business Faculty of Brawijaya University.

Saputra, S. (2007). Theoretical Study of Service Quality, Satisfaction, Trust, Reputation, Switching Cost \& Loyalty. Magazine Scientific Politeknik Six Monthly Pos Indonesia Competitive, 3(2).

Schneider, B., \& Bowen, D. E. (1999). Understanding Customer Delight and Outrage. Sloan Management Review, 35.

Singh, J., \& Deepak, S. (2000). Agency and Trust Mechanisms in Consumer Satisfaction and Loyalty judgments. Journal of the Academy of Marketing Science, 28(1), 150-167. https://doi.org/10.1177/0092070300281014

Siswar, D. S., \& Muhammad, B. (2011). The Role of Customer Delight and Its Effect on Customer's Response. Aceh Development International Conference.

Sudarmiyati, S. (2008). Customer Delight and Behavioral Intentions. Executive, 5(1).

Sung-wook, B., Ji, K. A., \& Lee, J. K. (2009). The Effects of Interactivity Constructs on Customer Loyalty in Mobile Environments. Pacific Asia Conference on Information Systems. 
Sureshchandar, G. S., Chandrasekharan, R., \& Anantharaman, R. N. (2002). The relationship between service quality and customer satisfaction. Journal of Services Marketing, 16(4). https://doi.org/10.1108/08876040210433248

Taleghani, M., Mahmood, S. L., \& Seyyed, J. M. (2011). The Investigation and analysis Impact of Brand Dimensions on Services Quality and Customers Satisfaction in New Enterprises of Iran. Contemporary Marketing Review, 1(6), 1-13.

Thurau, T. H., \& Alexander, K. (1997). The Impact of Customer Satisfaction and Relationship Quality on Customer Retention: A Critical reassessment and Model $\begin{array}{llll}\text { Development. } \quad \text { Psychology } \quad \& \quad \text { Marketing, } & \text { 14(8), }\end{array}$ https://doi.org/10.1002/(SICI)1520-6793(199712)14:8\%3C737::AID-MAR2\%3E3.0.CO;2-F

Thurau, T. H., Gwinner, K. P., \& Gremler, D. D. (2002). Understanding Relationship Marketing Outcomes: An Integration of Relational Benefits and Relationship Quality. Journal of Service Research, 4(3).

Ulusu, Y. (2011). Effects of Brand Image on Brand Trust. Journal of Yasar University.

Uma. (2009). Research Methods for Business: A Skill - Building Approach (5th edition). West Sussex: John Wiley \& Sons.

Verhoef, P. C., Franses, P. H., \& Hoekstra, J. C. (2002). The Effect of Relational Constructs on Customer Referrals and Number of Services Purchased From a Multiservice Provider: Does Age of Relationship Matter?. Journal of the Academy of Marketing Science, 30(3), 202-216. https://doi.org/10.1177/0092070302303002

Verma, H. V. (2003). Customer Outrage and Delight. Journal of Services Research, 3(1).

Walsh, M. F., Mittal, V., \& Page.Karen L. (2007). The Moderating Effect of Brand Commitment on Consumer Response to Shape Logo Redesign. Advances in Consumer Research, 34.

Waluyo, M. (2011). Guidelines and Application Structural Equation Modeling (To Application Research Models in Industrial Engineering, Psychology, Social and Management). Jakarta: Index.

Wang, J. S. (2009). Trust and relationship commitment between direct selling distributors and customers. African Journal of Business Management, 3(12), 862-870.

Westbrook, R. A., \& Richrard, L. O. (1991). The dimensionality of Consumption Emotion Pattem sand Consumer Satisfaction. Journal of Consumer Research, 18.

Wetzels, M., Ko, D. R., \& Marcel, V. B. (1998). Marketing service relationships: the role of commitment. Journal of Business \& Industrial Marketing, 13(4/5), 406-423. https://doi.org/10.1108/08858629810226708

Yamin, S., \& Heri, K. (2009). Structural Equation Modeling: Learning Easier Questionnaire Data Analysis Techniques with lisrel_PLS (2nd edition). Jakarta: Publisher Salemba Infotek. 


\section{Macrothink}

Case Studies in Business and Management ISSN 2333-3324 2017, Vol. 4, No. 2

Zeithaml, V. A., \& Bitner, M. J. (2000). Services Marketing (2nd edition). USA: McGraw-Hill.

\section{Copyright Disclaimer}

Copyright for this article is retained by the author(s), with first publication rights granted to the journal.

This is an open-access article distributed under the terms and conditions of the Creative Commons Attribution license (http://creativecommons.org/licenses/by/3.0/). 